\title{
Extracellular Matrix and Control of Proliferation of Vascular Endothelial Cells
}

\author{
Denis GospodarowiCZ and ChaRLES ILL, Cancer Research Institute and the \\ Departments of Medicine and Ophthalmology, University of California, \\ Medical Center, San Francisco, California 94143
}

A B S T R A C T Bovine vascular endothelial cells plated at low cell density in the presence of high $(10 \%)$ concentrations of serum and maintained on plastic tissue culture dishes proliferate slowly. If the cultures were exposed to fibroblast growth factors (FGF), the cells proliferated actively and, after a week, a monolayer composed of closely apposed and highly contact-inhibited mononucleated cells formed. In contrast to cultures maintained on plastic, cultures maintained on dishes coated with an extracellular matrix produced by corneal endothelial cells proliferated rapidly and no longer required FGF to reach confluence. Addition of FGF to such cultures did not decrease the mean doubling time, which was already at a minimum $(18 \mathrm{~h})$, nor did it result in a higher final cell density, which was already at a maximum $\left(700-1,000\right.$ cells $\left./ \mathrm{mm}^{2}\right)$. Likewise, although human umbilical vein endothelial cells plated at low density on plastic did not proliferate, they proliferated rapidly when plated on dishes coated with an extracellular matrix. However, unlike bovine vascular endothelial cells, they still required FGF if the cultures were to become confluent.

The ability of plasma vs. serum to sustain cell proliferation was analyzed using low density bovine-vascular endothelial cell cultures maintained either on plastic or on dishes coated with an extracellular matrix. Cells plated on plastic had a lower growth rate when exposed to plasma than to serum. In both cases, FGF was required for the cultures to become confluent. In contrast, when cells were plated on an extracellular matrix, they proliferated equally well, regardless of whether they were exposed to plasma or serum, and no longer required FGF to become confluent. Because the growth rate of the cultures maintained on an extracellular matrix was a direct function of the serum or plasma concentrations to which they were exposed, it is likely that the extracellular matrix had a permissive

Received for publication 19 November 1979 and in revised form 28 January 1980. rather than a direct mitogenic effect on the cells. Therefore, one can conclude that the simple change of substrate from plastic to extracellular matrix will restore the sensitivity of vascular endothelial cells to physiological agents present in plasma or serum.

\section{INTRODUCTION}

Earlier studies dealing with the control of cellular proliferation by epidermal and fibroblast growth factors $(\mathrm{FGF})^{1}$ have shown that cells that proliferate best in tissue culture retain their ability to produce an extracellular matrix (ECM), whereas cells that proliferate poorly or not at all have lost that ability (1). In particular, corneal endothelial cells, which respond particularly well to FGF when maintained in culture, retain their ability to synthesize and secrete an ECM found underneath but not on top of the cells (2). The appearance of this ECM has been shown to correlate with the acquisition by cultured corneal endothelial cells of their normal "in vivo" morphology, cell surface polarity, and function (3). The ECM produced by cells can promote the proliferation as well as stabilize the morphogenesis of the epithelia associated with them (4-6); therefore, in the present study, we have analyzed the proliferative behavior of the vascular endothelium when maintained on an ECM produced by corneal endothelial cells. These studies were prompted by a recent observation demonstrating that, although adrenal cortex or granulosa cells depend on FGF when maintained on plastic in order to proliferate, they no longer do so when maintained on dishes coated with an ECM produced by corneal endothelial cells (7). Because vascular and corneal endothelial cells are even more closely related cell types (3), using, as target cells, bovine and human vascular endothelial cells derived, respectively, from bovine aortic arch and human um-

\footnotetext{
${ }^{1}$ Abbreviations used in this paper: DMEM, H-16, Dulbecco's modified Eagle's medium; ECM, extracellular matrix; FGF, fibroblast growth factor; PBS, phosphate-buffered saline.
} 
bilical vein, we have investigated whether the ECM produced by corneal endothelial cells could support the growth of vascular endothelial cells.

The rates of proliferation of bovine vascular endothelial cells maintained on plastic vs. an ECM were compared. It was observed that low density vascular endothelial cell cultures, when maintained on plastic, do not respond to plasma and respond only poorly to serum, thereby requiring FGF for active proliferation $(8-10)$. The same cell type, when maintained on an ECM, required only plasma or serum and no longer depended on FGF in order to proliferate actively and reach a confluent stage. In the case of human vascular endothelial cells, although maintaining them on an ECM greatly increased their rate of proliferation, FGF was still required for the cultures to become confluent.

\section{METHODS}

Materials. FGF was purified as previously described from bovine brains (11). Purified collagen types I, II, III, and IV (A, B, and C chains) were a gracious gift from Dr. S. Tseng (University of California, San Francisco). Dulbecco's modified Eagle's medium (DMEM, H-16) was obtained from Grand Island Biological Co., Grand Island, N. Y. Calf and fetal calf serum were obtained from Irvine Serum Co. Fibronectin from bovine plasma was prepared as described (2). Tissue-culture dishes were from Falcon Labware, Div. of Becton, Dickinson \& Co., Oxnard, Calif., gentamycin from Schering Corporation, Kenilworth, N. J., and Fungizone from E. R. Squibb \& Sons, New York. Calf plasma and serum were prepared as described by Ross et al. $(12,13)$. Blood was drawn into plastic syringes containing $3.8 \%$ sodium citrate (1 vol citrate: 10 vol blood). The blood was then recalcified with $1 \mathrm{M} \mathrm{CaCl}_{2}$ to a final concentration of $14 \mu \mathrm{mol} / \mathrm{ml}$ and allowed to clot at room temperature for $2 \mathrm{~h}$. The clotted blood was then centrifuged at 2,000 $\mathrm{g}$ for $15 \mathrm{~min}$ at $4^{\circ} \mathrm{C}$. The serum was decanted from the clots and respun $(22,000 \mathrm{~g})$ for $30 \mathrm{~min}$ at $4^{\circ} \mathrm{C}$. The serum was dialyzed (Spectrapor-1, cutoff 6,000-8,000 mol wt) against Ringer's solution at $4^{\circ} \mathrm{C}$ for $24 \mathrm{~h}$. The serum was then filtered on a $0.2 \mu$ Millipore filter (Millipore Corp., Bedford, Mass.) and stored at $-70^{\circ} \mathrm{C}(13)$.

Plasma was prepared by drawing the blood into rechilled $\left(4^{\circ} \mathrm{C}\right)$ citrated syringes. All subsequent steps other than the recalcification and clotting were carried out at $4^{\circ} \mathrm{C}$. The blood was spun $(2,000 \mathrm{~g}$ for $15 \mathrm{~min})$ and the resulting plasma was pipetted off and respun $(22,000 \mathrm{~g}$ for $30 \mathrm{~min})$. At this point, the platelet-poor plasma was pooled and $1.0 \mathrm{M} \mathrm{CaCl}_{2}$ was added to a final concentration of $20 \mu \mathrm{mol} / \mathrm{ml}$. After a $2-\mathrm{h}$ incubation at $37^{\circ} \mathrm{C}$, the plasma was then spun $(22,000 \mathrm{~g}$ for 30 $\mathrm{min})$ to remove the fibrin clot and the supernate was dialyzed against Ringer's solution at $4^{\circ} \mathrm{C}$ for $24 \mathrm{~h}$. After dialysis, the plasma was respun $(22,000 \mathrm{~g}$ for $30 \mathrm{~min})$. The supernate was then filtered on a $0.2-\mu \mathrm{m}$ Millipore filter and frozen at $-70^{\circ} \mathrm{C}(13)$.

CM Sephadex chromatography of serum and plasma. 250 $\mathrm{ml}$ of serum or plasma prepared as described above were passed over a CM Sephadex C-50 column (total volume 300 $\mathrm{ml}$ ) equilibrated with $0.05 \mathrm{M}$ Na phosphates, $\mathrm{pH}$ 7.0. When the optical density of the eluant reached a plateau, collection was started. The first and last $30 \mathrm{ml}$ of the eluant were discarded. This chromatographic step has been described by Ross et al. (13) as further lowering the mitogenic activity of plasma by removing traces of platelet-derived growth factor(s).
Cell culture conditions. Cultures of bovine corneal endothelial cells were established from steer eyes as already described $(14,15)$. Stock cultures were maintained on tissue culture dishes in DMEM, H-16 supplemented with $10 \%$ fetal calf serum, $5 \%$ calf serum, $50 \mu \mathrm{g} / \mathrm{ml}$ gentamycin, and $2.5 \mu \mathrm{g} / \mathrm{ml}$ Fungizone. FGF ( $100 \mathrm{ng} / \mathrm{ml})$ was added every other day until the cells were nearly confluent. Cultures of bovine vascular endothelial cells were established from adult aortic arch as already described $(8-10)$. Stock cultures were maintained in the presence of DMEM, H-16 supplemented with $10 \%$ calf serum, $50 \mu \mathrm{g} / \mathrm{ml}$ gentamycin, $2.5 \mu \mathrm{g} / \mathrm{ml}$ Fungizone, and FGF $(100 \mathrm{ng} / \mathrm{ml})$ added every other day. Cultures of human umbilical endothelial cells were established from human umbilical cord as already described $(16,17)$. Stock cultures were maintained in the presence of Hepes buffered medium 199 supplemented with $10 \%$ calf serum, $50 \mu \mathrm{g} / \mathrm{ml}$ gentamycin, 2.5 $\mu \mathrm{g} / \mathrm{ml}$ Fungizone, and FGF (50) $\mathrm{ng}$ or $\mathrm{l} \mu \mathrm{g} / \mathrm{ml}$ added every other day). Bovine and human vascular endothelial cells were passaged every 7 and $12 \mathrm{~d}$, respectively, at a split ratio of 1:64. Cultures of bovine vascular smooth muscle cells were established from the vascular media of bovine aortic arch (11). Stock cultures were maintained in the presence of DMEM, $\mathrm{H}-16$ supplemented with $10 \%$ calf serum, $50 \mu \mathrm{g} / \mathrm{ml}$ gentamycin, and $2.5 \mu \mathrm{g} / \mathrm{ml}$ Fungizone. FGF (100 ng/ml) was added every other day until cultures became confluent. Stock cultures were passaged weekly at a split ratio of $1: 64$.

Preparation of plates coated with ECM, different types of collagen, or fibronectin. Corneal endothelial cells were plated at an initial density of $10^{4}$ cells $/ 35-\mathrm{mm}$ dish and maintained in the presence of DMEM, H-16 supplemented with $10 \%$ fetal calf serum, $5 \%$ calf serum, $5 \%$ dextran T-40, 50 $\mu \mathrm{g} / \mathrm{ml}$ gentamycin, and $2.5 \mu \mathrm{g} / \mathrm{ml}$ Fungizone. FGF $(100 \mathrm{ng} / \mathrm{ml})$ was added every other day $(7,15)$. Once the plates became confluent (ordinarily within $6 \mathrm{~d}$ ) and signs of basement membrane formation could be observed by phase-constant microscopy, the cultures were washed with phosphate-buffered saline (PBS) and then exposed for $30 \mathrm{~min}$ to PBS containing $0.5 \%$ Triton X-100 ( $\mathrm{vol} / \mathrm{vol})$. Once the nuclei and the basement membranes became clearly visible, the cultures were washed three times with PBS. After these washings, only a few cytoskeletons and nuclei could be observed associated with an intact ECM. Examination of the plates by scanning electron microscopy (7) has conclusively shown that the entire surface of the plates was covered by a thick layer of amorphous material. The composition of the ECM has been analyzed, by radioiodination with ${ }^{131} \mathrm{I}-\mathrm{Na}$ using the lactoperoxydase glucose oxydase method followed by slab gel electrophoresis and autoradiography $(2,3)$. Fibronectin and collagen were among the main components present $(2,3)$. Serum proteins that could have been adsorbed on the ECM were not detected (2). The composition of the ECM has also been analyzed by indirect immunofluorescence using purified antibodies against fibronectin and collagen types, I, III, and IV. Fibronectin and collagen types III and IV were the main components that fluoresced markedly $(2,18)$. To check for the possible adsorption of FGF to the ECM produced by corneal endothelial cell cultures, ${ }^{125} \mathrm{I}-\mathrm{FGF}\left(10^{5} \mathrm{cpm} / \mathrm{ml}\right)$ was added every other day together with $100 \mathrm{ng} / \mathrm{ml}$ of unlabeled FGF. ECM, prepared as described above, was then solubilized with $1 \mathrm{ml}$ of $0.5 \mathrm{~N} \mathrm{NaOH}$ and counted in a Beckman $\alpha$-scintillation counter, Beckman Instruments, Inc., Fullerton, Calif. Less than 100 cpm was found to be associated with the ECM. This represents an adsorption to the ECM that is $<0.1 \%$ of the FGF concentration to which cells were exposed. Therefore, at most, 0.1 ng of FGF is adsorbed to the ECM coating the dishes. This concentration is well below that required to induce maximal cell proliferation, and the permissive effect of the ECM on cell proliferation cannot be explained by the adsorption of 
FGF onto it when confluent corneal endothelial cultures are first prepared. Similar results were obtained regardless of whether dishes coated with an ECM were prepared from confluent cultures grown in the presence of FGF (secondary or late passage cultures) or in its absence (primary cultures).

To coat dishes with different types of collagen, $50 \mu \mathrm{l}$ of a solution of $2-5 \mathrm{mg}$ collagen $/ \mathrm{ml}$ was applied to a $35-\mathrm{mm}$ dish and spread uniformly with a rubber policeman. The plates were then exposed to ammonia vapor for $30 \mathrm{~min}$ and washed extensively with PBS $(1,7,19)$. Alternatively, dishes coated with collagen were allowed to dry at room temperature (20). Dishes were then sterilized by exposure to ultraviolet light (20). To coat dishes with fibronectin, $2 \mathrm{ml} \mathrm{of} 30 \mu \mathrm{g} / \mathrm{ml}$ of fibronectin in $0.05 \mathrm{M}$ urea was added to the dishes. After an incubation period of $60 \mathrm{~min}$ at $22^{\circ} \mathrm{C}$, the dishes were washed five times with PBS (21). Control plates coated either with an ECM or collagens were further examined by scanning electron microscopy and were found to be uniformly covered with an amorphous material.

Cell growth measurement. Cells were plated on plastic dishes or dishes coated with an ECM at an initial density of 1 or $2 \times 10^{4}$ cells/35-mm dish. FGF was added every other day at a concentration of $100 \mathrm{ng} / \mathrm{ml}$. Triplicate plates were trypsinized and counted with a Coulter counter (Coulter Electronics Inc., Hialeah, Fla.) every other day. Morphological appearances of the cultures was analyzed by phase-constant microscopy, and pictures were taken once the cultures maintained on ECM or plastic became confluent.

Determination of the culture lifetime of vascular endothelial cells maintained on dishes coated with an ECM. Bovine vascular endothelial cells were plated at an initial density of $10^{4}$ cells/35-mm dish in $2 \mathrm{ml}$ of DMEM, H-16 supplemented with $10 \%$ calf serum, $50 \mu \mathrm{g} / \mathrm{ml}$ gentamycin, and $2.5 \mu \mathrm{g} / \mathrm{ml}$ Fungizone. $8 \mathrm{~h}$ later, triplicate plates were trypsinized and counted to determine the plating efficiency. After $7 \mathrm{~d}$, triplicate cultures were trypsinized to determine the final cell density. Cultures were counted and transferred weekly at a cell density of $10^{4}$ cells $/ 35-\mathrm{mm}$ dish. The number of generations was determined from the initial cell density $8 \mathrm{~h}$ after seeding and the number of cells harvested at each transfer.

\section{RESULTS}

Growth and morphological appearance of cultured bovine and human vascular endothelial cells maintained on plastic is. ECM and either exposed or not to FGF. When the growth of bovine vascular endothelial cells maintained on plastic vs. ECM was compared, cells maintained on an ECM, whether exposed or not to FGF, reached a final cell density within 5 d, which was 10-12-fold that of cultures maintained on plastic alone. Cultures maintained on plastic and exposed to FGF had a growth rate similar to that of cultures maintained on ECM, regardless of whether or not they were exposed to FGF (Fig. 1A). Addition of FGF to cultures maintained on an ECM did not decrease their mean doubling time, which was already at a minimum $(18-20 \mathrm{~h})$, nor did it result in a higher final cell density, which was already at a maximum (700-1,000 cells $\left./ \mathrm{mm}^{2}\right)$. When the morphology of confluent cultures of bovine vascular endothelial cells maintained on plastic and exposed to FGF was compared with that of confluent cultures maintained on ECM, it was found to be similar (Fig. 1C and D).
In contrast to bovine vascular endothelial cells, human umbilical vein endothelial cell cultures did not proliferate when seeded at low cell density on tissue culture dishes (Fig. 1B). As previously reported (10, 17), addition of FGF to the cultures induced the cells to divide actively and, within $11 \mathrm{~d}$, a 15 -fold increase in cell numbers was observed. When cells were seeded on ECM instead of on plastic, a six-fold increase in cell number was observed over the same period of time. In contrast, with bovine endothelial cell cultures, FGF was still required if cultures maintained on ECM were to reach confluence (Fig. 1B). Addition of FGF to cultures maintained on ECM induced an optimal growth rate, and the cultures became confluent within $11 \mathrm{~d}$. The final cell density of the confluent cultures was 20-fold higher than that of cultures maintained on plastic and not exposed to FGF. When the morphological appearance of confluent cultures maintained on plastic (Fig. 1E) vs. ECM (Fig. 1F) and exposed in both cases to FGF was compared, the cultures maintained on ECM were composed of cells more closely apposed and tightly packed than those maintained on plastic.

Serum requirement for the proliferation of bovine vascular endothelial cells maintained on plastic vs. ECM. As shown in Fig. 2, the rate of proliferation of bovine vascular endothelial cells maintained on plastic and exposed to FGF (Fig. 2B), or maintained on an ECM and not exposed to FGF (Fig. 2A), was a strict function of the serum concentration to which the cultures were exposed. Although cells maintained on an ECM and exposed to serum concentration as low as $1 \%$ proliferated actively even in the absence of FGF (Fig. 2A), cells maintained on plastic, when exposed to a serum concentration as high as $10 \%$, proliferated poorly (Fig. 2B). In contrast, if FGF was added to such cultures, then active proliferation resumed and its rate was a direct function of the serum concentration to which cultures were exposed. (Fig. 2B).

Therefore, it can be concluded that when the proliferation of bovine vascular endothelial cells maintained on plastic vs. an ECM is compared, low density cell cultures maintained on plastic and plated at low density proliferate poorly. Therefore, FGF is needed for the cultures to become confluent within a few days. In contrast, when the cultures are maintained on ECM, they proliferate actively and no longer require $\mathrm{FGF}$ in order to become confluent. In both cases (either maintained on plastic and exposed to FGF or maintained on an ECM), the rate of proliferation was a direct function of the serum concentration to which cultures were exposed. Because cells still required serum in order to proliferate, it is likely that the effect of the ECM is more a permissive than a direct mitogenic one.

Proliferation of vascular endothelial cells on dishes coated with different types of collagen or with fibronectin. To test the possibility that collagen or fibro- 

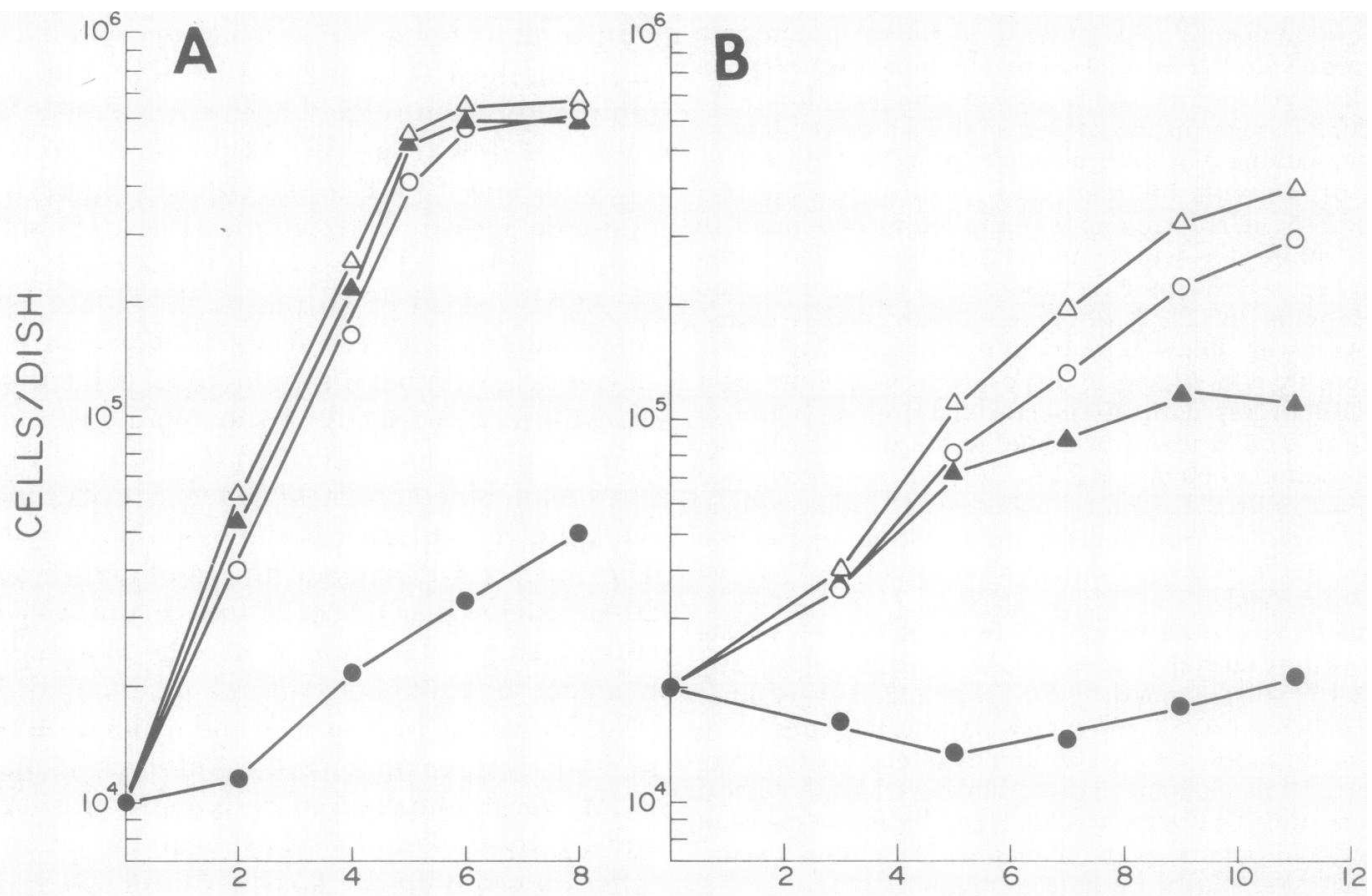

DAYS
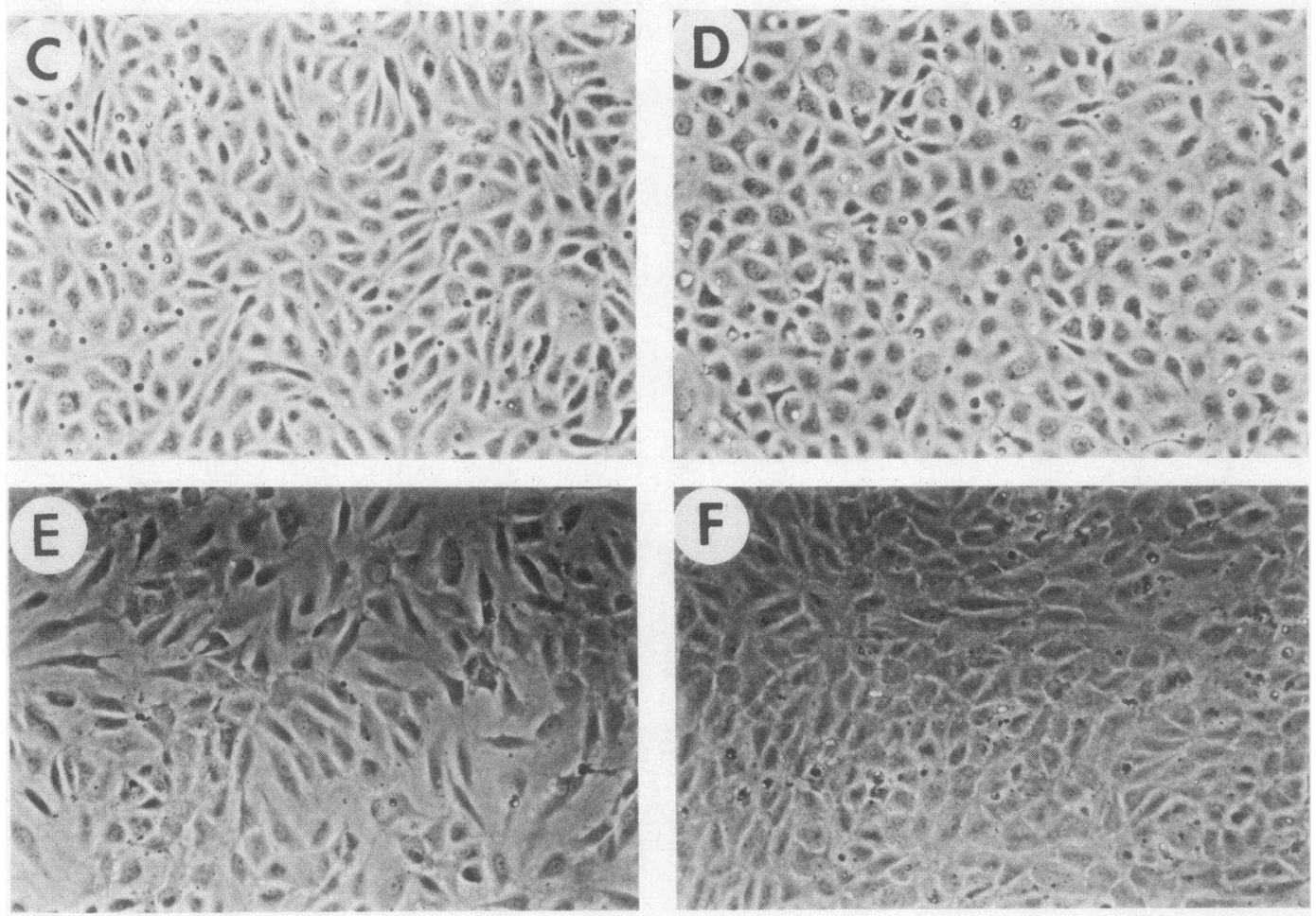

FIGURE 1 Proliferation and morphological appearance of bovine aortic endothelial cells and human umbilical vein endothelial cells when maintained on plastic vs. ECM and either exposed or not to FGF. (A) Bovine vascular aortic endothelial cells were plated at an initial density of $1 \times 10^{4}$ cells/35-mm dish coated $(\triangle, \Delta)$ or not $(O, \bullet)$ with an ECM. Cultures were maintained in the presence of DMEM supplemented with $10 \%$ calf serum, with $(\triangle, O)$ or without $(\Lambda, \bullet)$ FGF $(100 \mathrm{ng} / \mathrm{ml})$ being added every other day. (B) Human vascular endothelial cells were plated at 


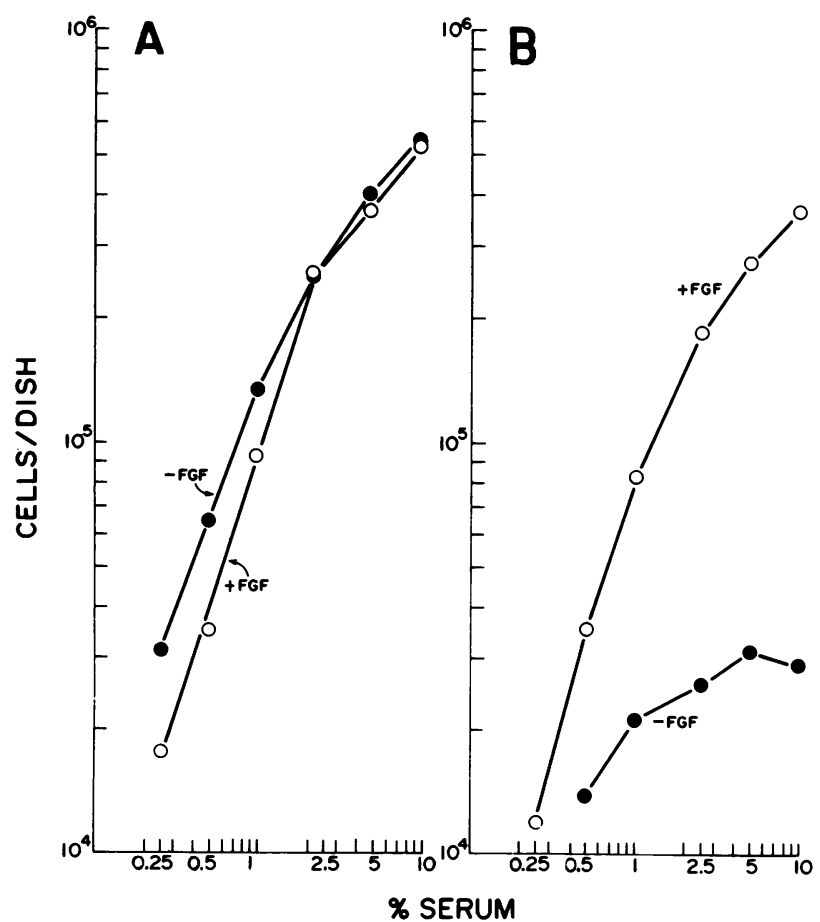

FIGURE 2 Comparison of the rates of proliferation of bovine vascular endothelial cells maintained on plastic vs. an ECM as a function of the serum concentration to which they were exposed. Bovine vascular endothelial cells were plated at $10^{4}$ cells/35-mm dish coated either with an ECM (A) or not (B). Cultures were maintained for $8 \mathrm{~h}$ in the presence of DMEM, $\mathrm{H}-16$ supplemented with $10 \%$ serum, $50 \mu \mathrm{g} / \mathrm{ml}$ gentamycin, and $2.5 \mu \mathrm{g} / \mathrm{ml}$ Fungizone. After $8 \mathrm{~h}$, the medium was removed and the cultures washed once with DMEM, H-16. DMEM, H-16 supplemented with $2.5 \mu \mathrm{g} / \mathrm{ml}$ Fungizone, $50 \mu \mathrm{g} / \mathrm{ml}$ gentamycin, and various concentrations of serum was then added to the dishes $(O, O)$. To half of the dishes, FGF $(100 \mathrm{ng} / \mathrm{ml})$ was added every other day $(O,+F G F)$. After $5 \mathrm{~d}$ the cultures were trypsinized and counted.

nectin alone could be the component of the ECM responsible for the increased rate of proliferation of cells plated on it, we have compared the growth of bovine vascular endothelial cells plated on dishes coated with purified collagen types I, II, III, and IV or with fibronectin. In no case did the cultures significantly increase their rate of growth when maintained on these different substrates (Fig. 3). In all cases, an aberrant morphological appearance was observed, the cultures being composed of large cells of which a high proportion are binucleated (unpublished results). Only cells

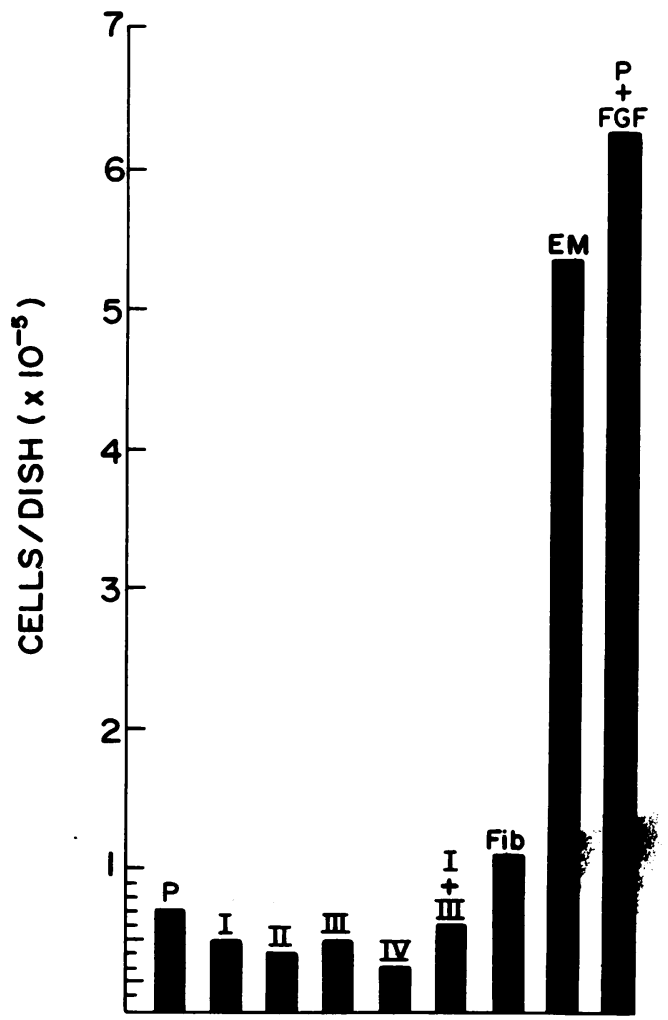

Figure 3 Proliferation of bovine vascular endothelial cells maintained on different substrates. Bovine vascular endothelial cells $\left(2 \times 10^{4}\right.$ cells/35-mm dish) were seeded on dishes coated with collagen types I, II, III, and IV, with collagen types I and III, with fibronectin (Fib), or with an ECM (EM). Cultures were maintained in the presence of DMEM, H-16 supplemented with $10 \%$ calf serum, $50 \mu \mathrm{g} / \mathrm{ml}$ gentamycin, and $2.5 \mu \mathrm{g} / \mathrm{ml}$ Fungizone. After $5 \mathrm{~d}$ the cultures were trypsinized and the cells counted. The final cell density was compared with that of cultures maintained for the same period of time on plastic (P) and exposed or not to FGF (P + FGF).

maintained on an ECM proliferated actively (Fig. 3), reaching confluence within $5 \mathrm{~d}$. This observation, therefore, excludes the possibility that the component in the ECM produced by corneal endothelial cells, which could have a permissive effect on their proliferation, is either collagen or fibronectin alone.

Proliferation at clonal density of vascular endothelial cells maintained on plastic vs. ECM. Proliferation of cells in culture is not only a function of the medium, serum, or growth factor(s) to which cells are exposed; it is also a function of cell density. Although

an initial density of $2 \times 10^{4}$ cells/35-mm dish coated $(\Delta, \Delta)$ or not $(O, O)$ with an ECM. Cultures were maintained in the presence of DMEM supplemented with $10 \%$ calf serum, with $(\triangle, O)$ or without $(\Lambda, 0)$ FGF $(100 \mathrm{ng} / \mathrm{ml})$ being added every other day. The morphological appearance of bovine vascular endothelial cells maintained on plastic and grown in the presence of FGF, or maintained on an ECM and grown in the absence of FGF, is shown in C and D, respectively. The morphological appearance of human umbilical vein endothelial cells maintained on plastic or on an ECM and grown in both cases in the presence of FGF is shown in E and F, respectively. Pictures were taken once the culture reached confluence (phase contrast, $\times 100$ ). 
at high cell density cells can rapidly condition their medium, thereby compensating for the nutrient deficiency of the medium, when plated at clonal density they can no longer do so. Therefore, factors or nutrients required for cell survival and proliferation may be more readily apparent when cells are maintained at low rather than high density. In particular, requirements for a proper substrate could become apparent. Although cells maintained at high density could readily make a basement membrane, thereby facilitating further proliferation, at clonal density, even if every cell were to produce a basement membrane, it would be extremely difficult for them to cover the whole dish in a reasonable period of time. We have, therefore, analyzed the proliferation of vascular endothelial cells plated at clonal density on plastic vs. plates coated with an ECM. As can be seen (Fig. 4), when cells were plated at low cell density on plastic, the plating efficiency was extremely poor or cells died rapidly because no clones were visible after $10 \mathrm{~d}$. If FGF was present in the medium, $25 \%$ of the cells gave rise to individual clones. In contrast, when cells were plated at low density on an ECM, not only was a $90 \%$ plating efficiency observed at all cell densities (from 0.012 to 1.2 cells $/ \mathrm{mm}^{2}$ ) but, in addition, all cells gave rise to clones even in the absence of FGF. This demonstrates that the substrate upon which cells rest, even at clonal density, is crucial to insure both their survival and proliferation in response to serum factors.

The proliferative response to plasma vs. serum of

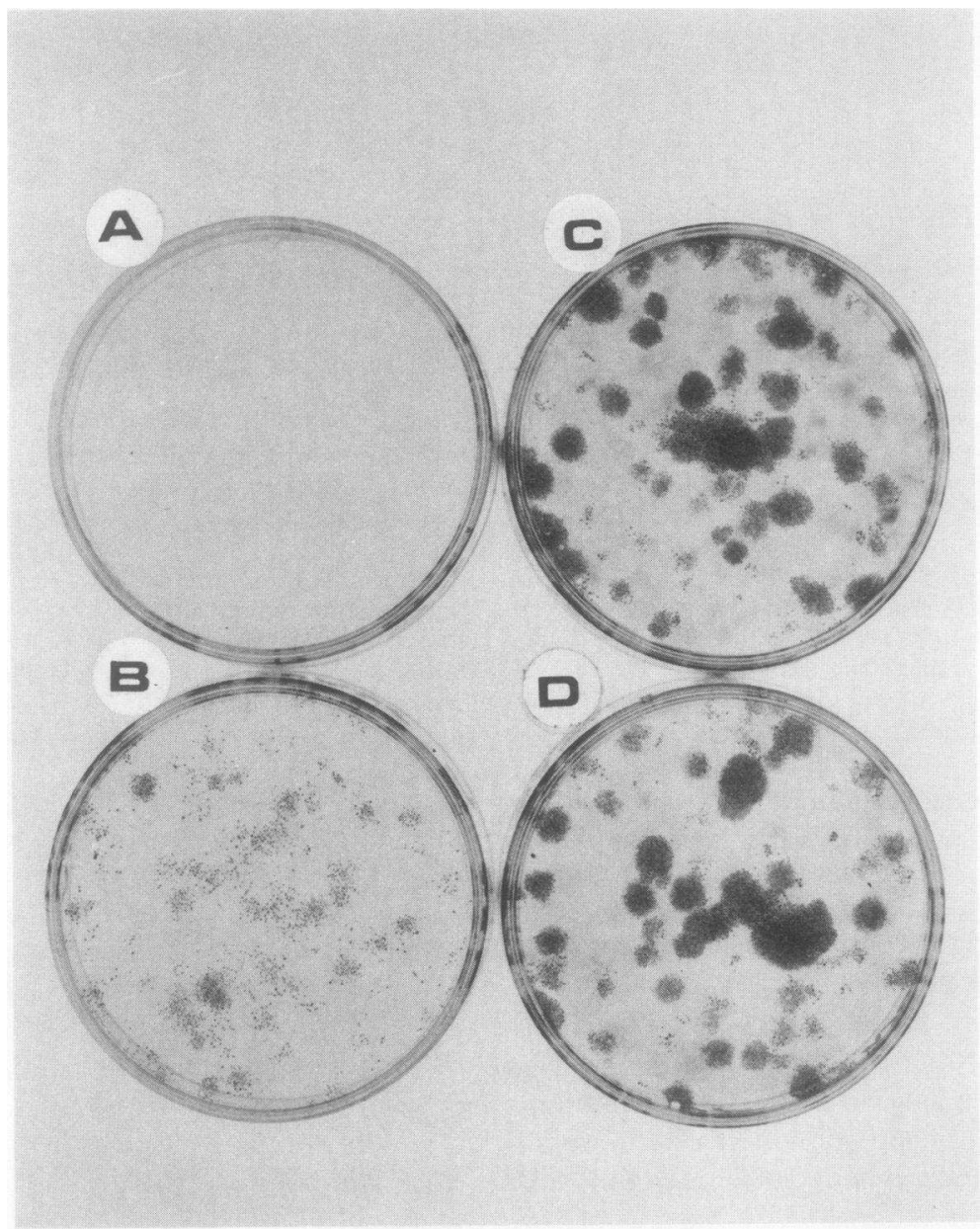

Figure 4 Proliferation at a clonal density of bovine vascular endothelial cells maintained on plastic vs. an ECM and exposed or not to FGF. Bovine vascular endothelial cells ( 50 cells $/ 35-\mathrm{mm}$ dish) were seeded either on plastic dishes (A, B) or dishes coated with an ECM (C, D). Cultures were maintained in the presence of DMEM, H-16 supplemented with $10 \%$ calf serum, $50 \mu \mathrm{g} / \mathrm{ml}$ gentamycin, and $2.5 \mu \mathrm{g} / \mathrm{ml}$ Fungizone. To half of the dishes (B, D), FGF $(100 \mathrm{ng} / \mathrm{ml})$ was added every other day. After $10 \mathrm{~d}$ (with a medium change on day 5) the medium was removed and the cultures were washed once and fixed with $10 \%$ formalin in PBS. Cultures were then stained with $0.1 \%$ crystal violet. 
bovine vascular endothelial cells maintained on plastic vs. ECM. Earlier results $(8,9)$ have shown that bovine vascular endothelial cells maintained on plastic, like vascular smooth muscle cells (9), respond poorly to plasma but proliferate actively when maintained in the presence of serum. However, previous observations with vascular smooth muscle cells have demonstrated that when cells are maintained on an ECM, they proliferate as well in the presence of serum as in plasma (22). The close contact between the cells and the ECM could, therefore, have restored their sensitivity to physiological factors normally present in plasma, and the posited differences in mitogenic activity between plasma and serum vanish.

To extend our observations regarding the essential similarity between plasma and serum, with regard to their promotion of cell growth when cells are maintained on an adequate substrate, we have compared the responses of bovine vascular endothelial cells main- tained on plastic or ECM with both plasma and serum. As shown in Fig. 5A, bovine vascular endothelial cells maintained on plastic and exposed to plasma hardly proliferate, undergoing only one doubling in $10 \mathrm{~d}$. In contrast, when FGF was added to the cultures, the cells rapidly divided. After $10 \mathrm{~d}$ there was a 30 -fold increase in cell number (Fig. 5A). The final cell density of cultures maintained on plastic and exposed to plasma and FGF was higher than that of cultures maintained on plastic and exposed to serum alone (Fig. 5B). This demonstrates that the addition of FGF to the medium of cells maintained on plastic can more than compensate for the difference between plasma and serum. Cultures maintained on plastic and exposed to serum (Fig. 5B) go through two to three doublings over a period of $10 \mathrm{~d}$. Addition of FGF decreased the mean doubling time of the cultures from $48-60 \mathrm{~h}$ to $20 \mathrm{~h}$ during their logarithmic growth phase. It also increased the final cell density of the cultures by 10 -fold over that of

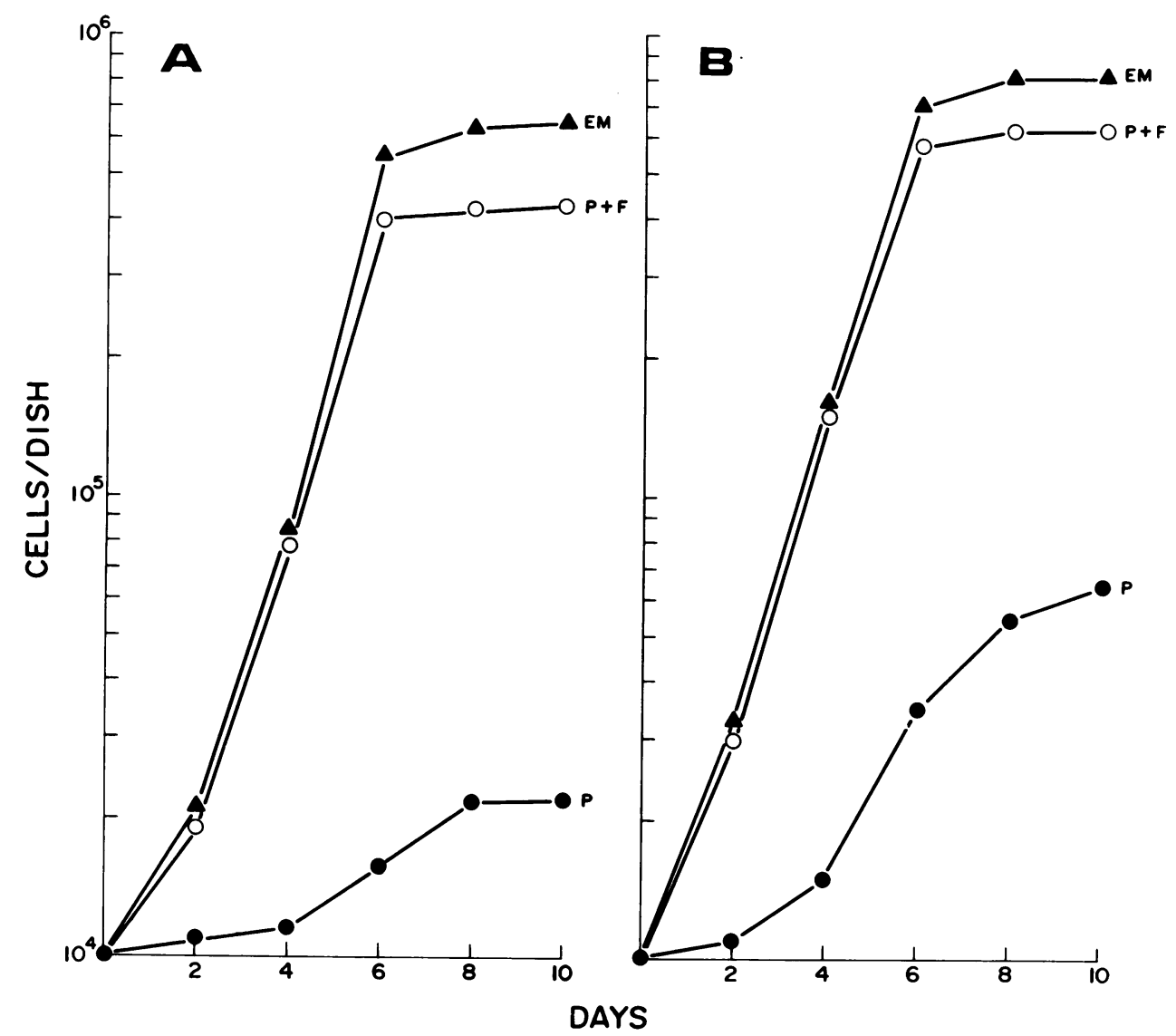

FIGURE 5 Comparison of the growth rates of bovine vascular endothelial cells maintained on an ECM vs. plastic and exposed to either plasma (A) or serum (B). Bovine vascular endothelial cells were plated at an initial cell density of $10^{4}$ cells/35-mm dish on either plastic dishes $(O, O, P)$ or dishes coated with an ECM $(\boldsymbol{\Lambda}, \mathrm{EM})$. The cultures were maintained in the presence of DMEM, $\mathrm{H}-16$ supplemented with $50 \mu \mathrm{g} / \mathrm{ml}$ gentamycin, $2 \mu \mathrm{g} / \mathrm{ml}$ Fungizone, and with either $10 \%$ bovine plasma (A) or $10 \%$ bovine serum (B) added. Cultures were exposed $(\mathrm{O}, \mathrm{P}+\mathrm{F})$ or not $(\boldsymbol{O}, \boldsymbol{\Delta})$ to FGF (100 $\mathrm{ng} / \mathrm{ml}$, added every other day). 
cultures exposed to serum alone and by 30 -fold over that observed with cells maintained in the presence of plasma alone. In contrast, when cells were maintained on an ECM, they proliferated equally well, regardless of whether they were exposed to plasma (Fig. 5A) or serum (Fig. 5B). The mean doubling time of the cultures exposed to plasma or serum was the same $(18-20 \mathrm{~h})$ during their logarithmic growth phase. The final cell density when cultures became confluent was similar in both cases. Therefore, one could conclude that, although FGF greatly increases the growth rate of cultures exposed to plasma and, to a lesser extent, that of cultures exposed to serum, when cells are maintained on an ECM and exposed to either plasma or serum, they proliferate equally well and no longer require FGF. Therefore, there ceases to be any observable difference in mitogenic activity between plasma and serum.

Chromatography of plasma or serum on CM Sephadex did not affect their abilities to promote the growth of vascular endothelial cells maintained on an ECM. Under these conditions, plasma or serum was equally effective in supporting cell growth (Table I, Fig. 6). Similar results were obtained when the proliferation of vascular smooth muscle cells, maintained on ECM and exposed to either plasma or serum adsorbed or not on CM Sephadex, was compared (Table I, Fig. 6). In fact, adsorption of plasma or serum on CM Sephadex slightly improved the rate of growth of these cells.

Fig. 7 compares the morphological appearance of bovine vascular endothelial cell cultures maintained on plastic (Fig. 7A-D) vs. ECM (Fig. 7E and F) and grown in the presence of serum (Fig. 7A, C, and E) or plasma (Fig. 7B, D, and F). Although cultures main- tained on plastic and exposed to either serum or plasma were composed of large cells that were in some cases binucleated and vacuolated (Fig. 7A and B), addition of FGF to the medium resulted in cultures that formed a monolayer composed of small, mononucleated, and closely apposed cells that did not overgrow each other (Fig. 7C and D). In contrast, cultures maintained on an ECM formed a highly contact-limited cell monolayer, regardless of whether they were exposed to serum (Fig. 7E) or plasma (Fig. 7F), and no longer required FGF (cf. Fig. 7A and B with Fig. 7E and F).

The permissive effect of the ECM. To decide whether it was the ECM itself that was mitogenic for cells plated on it, whereas the plasma or serum had a permissive effect, or if the converse was true, i.e., that cells maintained on an ECM become sensitive to plasma or serum factors to which they were prevented from responding when attached to plastic, cultures maintained on plastic vs. an ECM were exposed to increasing concentrations of serum or plasma. The cultures were then counted at the end of their logarithmic growth phase (Fig. 8). If the ECM has a permissive effect and the proliferation of the cells is dependent on serum or plasma factors, one would expect that the cultures, when exposed to increasing concentrations of serum or plasma, would proliferate at a rate directly proportional to the plasma or serum concentration to which they are exposed. If the ECM itself is mitogenic, one would then expect little difference in the rates of proliferation of cultures exposed to different concentrations of serum or plasma. As shown in Fig. 8, the rate of proliferation of cultures maintained on an ECM was a direct function of the serum concentration to which the cells were exposed. It is thereby

TABLE I

Comparison of the Rates of Proliferation of Bovine Vascular Endothelial and Vascular Smooth Muscle Cells When Maintained on Plastic vs. an ECM and Exposed to Serum or Plasma That Has or Has Not Been Chromatographed on a CM Sephadex Column

\begin{tabular}{|c|c|c|c|c|}
\hline & \multicolumn{2}{|c|}{ Plastic } & \multicolumn{2}{|c|}{ ECM } \\
\hline & Endothelial cells & Smooth muscle cells & Endothelial cells & Smooth muscle cells \\
\hline & \multicolumn{2}{|c|}{ cells/dish $\times 10^{3}$} & \multicolumn{2}{|c|}{ cells/dish $\times 10^{3}$} \\
\hline Serum & 72 & 146 & 935 & 473 \\
\hline Serum-CMS* & 46 & 58 & 926 & 496 \\
\hline Plasma & 30 & 11 & 836 & 360 \\
\hline Plasma-CMS* & 24 & 15 & 766 & 423 \\
\hline
\end{tabular}

$1 \times 10^{4}$ vascular endothelial or smooth muscle cells were seeded in the presence of $2 \mathrm{ml}$ of DMEM, H-16 supplemented with $10 \%$ calf serum or plasma on $35-\mathrm{mm}$ plastic dishes coated or not with an ECM. $8 \mathrm{~h}$ later the media were removed, the plates were washed once with DMEM, H-16, and $2 \mathrm{ml}$ of DMEM, H-16 containing either $10 \%$ serum or plasma that had (plasma CMS and serum CMS) or had not (plasma, serum) first been adsorbed on a CM Sephadex C50 column, were added to the plates. 5 and $7 \mathrm{~d}$ later, for vascular endothelial and smooth muscle cells, respectively, triplicate plates were trypsinized and counted.

* CMS, CM sephadex. 


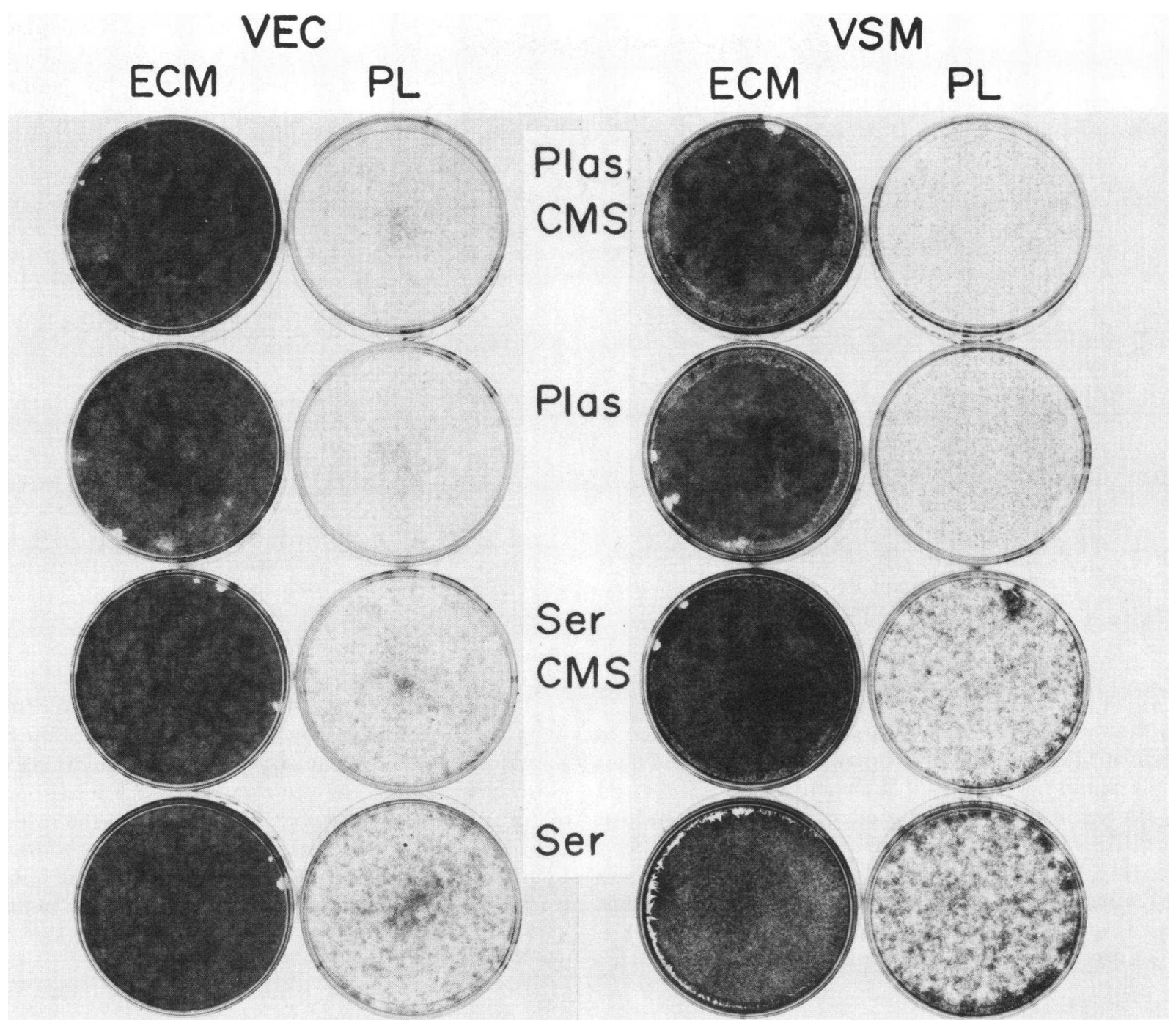

FIGURE 6 Effect of substratum, plasma, or serum on the proliferation of vascular endothelial and smooth muscle cells. $10^{4}$ bovine vascular endothelial cells (VEC) or smooth muscle cells (VS.M) were plated in 35-mm dishes coated (ECM) or not (PL) with an ECM. Cultures were maintained in the presence of $10 \%$ plasma (Plas) or serum (Ser). Their growth rate was compared with that of cultures exposed to $10 \%$ plasma or serum adsorbed on a CM Sephadex C50 column as described in the text. 5 and $7 \mathrm{~d}$ later, for VEC and VSM cultures, respectively, dishes were washed, fixed with $10 \%$ formalin, and stained with $0.1 \%$ crystal violet.

demonstrated that the effect of the ECM is a permissive one and, as such, makes cells sensitive to plasma factor(s). Furthermore, because the growth rate of cells maintained on ECM and exposed to increasing concentrations of serum or plasma is roughly similar, it is likely that the cells responded to the same factor(s) in both cases.

Effect of the ECM on the culture lifetime of bovine vascular endothelial cells. Vascular endothelial cells maintained in tissue culture on plastic and in the absence of FGF have a finite life-span that does not exceed 50 generations, even when cultures are passaged at a high cell density $(23,24)$. This life-span can be considerably shortened when cultures are passaged at low cell density $(23,24)$. Previous results have shown that addition of FGF to cultures passaged at low cell density on plastic considerably increases the lifetime of the cultures $(8-10,17,24)$. Because cultures maintained on ECM no longer require FGF in order to proliferate actively, we have also investigated its effect on the lifetime of vascular endothelial cells. Cultures that had been maintained on plastic in the presence of FGF for 50 generations and that had been shown to senesce rapidly as soon as FGF was no longer added 

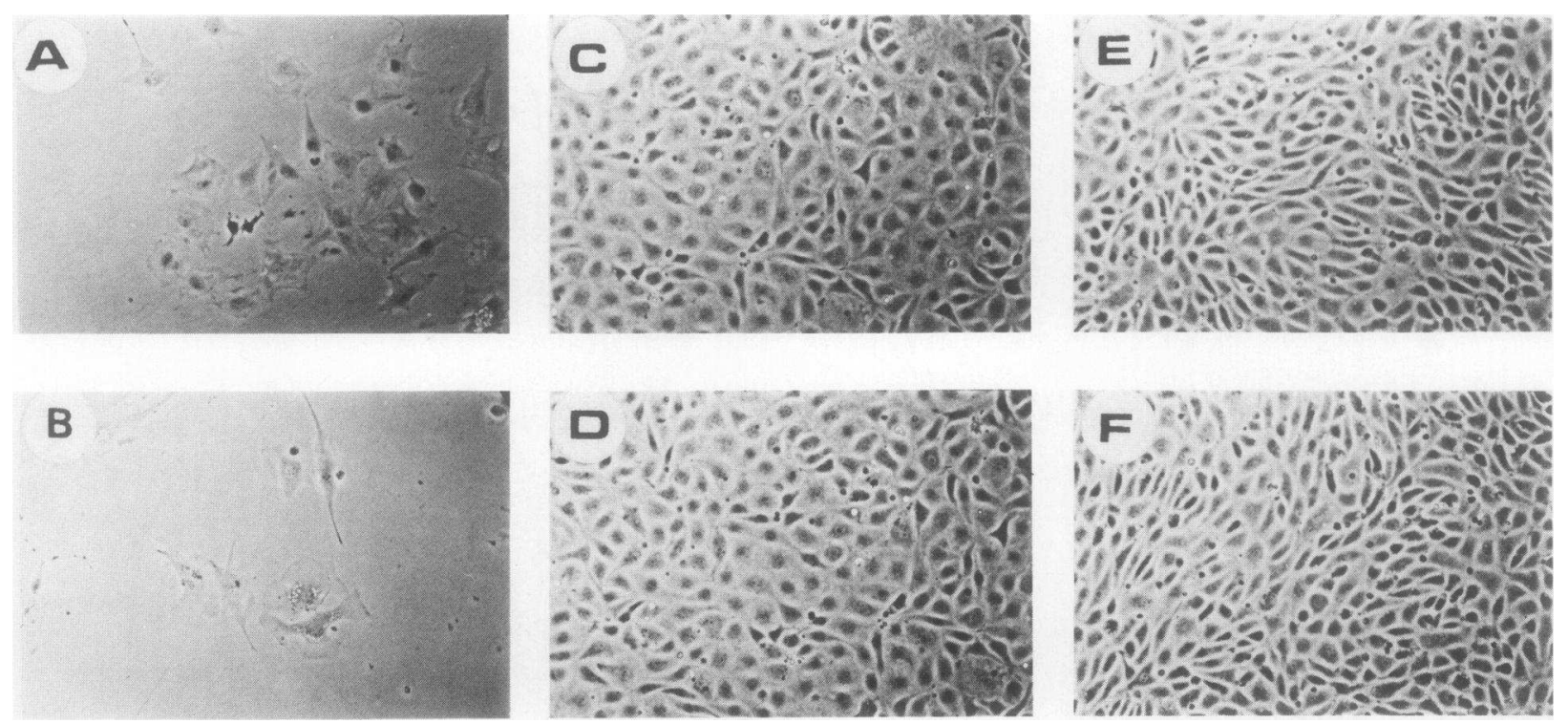

FIGURE 7 Morphological appearance of bovine vascular endothelial cells maintained on plastic substrate (A-D) or an ECM (E, F) and exposed to $10 \%$ serum (A, C, E) or $10 \%$ plasma (B, D, F). Cultures were plated and maintained as described in Fig. 5 and exposed (C, D) or not (A, B, E, F) to FGF. Pictures were taken on day 6 (phase contrast, $\times 100$ ).

to the media (24) were maintained in the absence of FGF on dishes coated with an ECM (Fig. 9). When maintained on such a substrate, the cells proliferated actively and could be passaged weekly at a split ratio of 1:95. 50 generations later, the cultures still proliferated actively, although with a longer average doubling time (Fig. 9). Therefore, it is demonstrated that cells maintained on ECM have a much longer life-span in culture than do cells maintained on plastic alone.

\section{DISCUSSION}

A number of laboratories (23-28) are now routinely maintaining human or bovine vascular endothelial cells in culture. The only limitations are that the cultures have a short life-span (20-40 generations) and must be passaged at a low split ratio (up to 1:10). These limitations could either be inherent in this cell type or could reflect the tissue culture conditions under which the cells are maintained. Particularly important in this regard is the substrate upon which the cells are maintained.

In vivo, cells rest on an ECM. It is on this natural substrate that cells will migrate, proliferate, and differentiate. This substrate is composed in large part of different types of collagen (29), glycosaminoglycans, proteoglycan (30), and glycoproteins, among which is fibronectin, which has been shown to be a ubiquitous component of various types of ECM (31). Early studies done by Dodson (32) and Wessels (33) demonstrated a requirement on the part of the basal cell layer of the epidermis for a proper substrate in order for the cells to proliferate. Likewise, Cohen (34) has shown that the basal cell layer of the epidermis must be in close contact with the dermis if cells are to respond to epidermal growth factor. Investigation of the role of extracellular materials at the epithelial-mesodermal interface has shown that collagens and mucopolysaccharides present as major molecular species at the junction of interacting tissues could be implicated in epithelial morphogenesis $(35,36)$.

After the pioneering studies of Ehrmann and Gey (37), numerous studies have shown that collagen, one of the main components of ECM, is important in promoting cell attachment $(20,38,39)$, migration $(40)$, proliferation $(39,41-43)$, and differentiation (43-47). Fibronectin, another component of the ECM, has also been reported to promote cell attachment $(48,49)$ as well as cell proliferation (21).

However, the effect of the ECM on the proliferation of cells maintained in culture has not been studied. This is mostly because, with the exception of lens capsule, it is difficult in vivo to isolate such material from neighboring tissues. In vitro, the reconstitution of an ECM from its separate elements (collagens, proteoglycans, glycosaminoglycans, and glycoproteins) may be equally difficult because, not only must the correct ratio of these components be respected, but they must also be linked in such a way that the resulting tridimensional structure will be like that of the extracellular scaffolding in vivo. The problem in reconstituting an ECM in vitro is made even more difficult by the fact that collagen types IV and V, which are the 


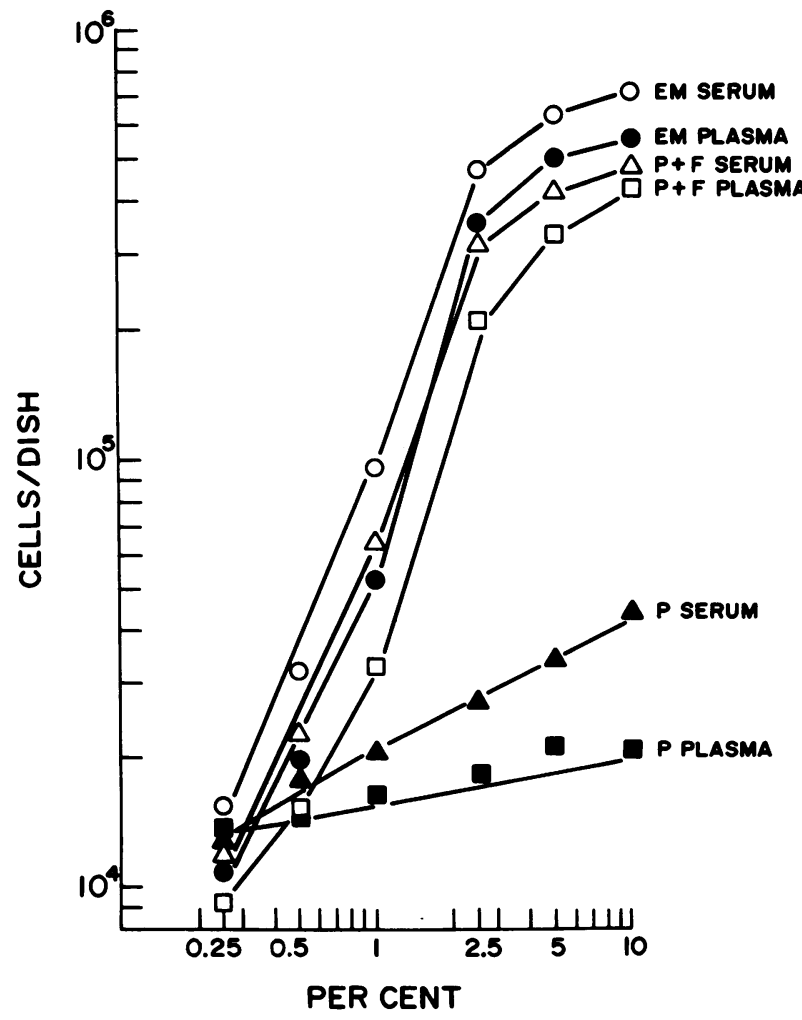

FIGURE 8 Dependence on plasma for proliferation of bovine vascular endothelial cells when the cells are maintained on an ECM. Vascular endothelial cells were plated at 10,000 cells/ 35-mm dish on plastic (P) or on an extracellular matrix (EM). Cultures were maintained for $8 \mathrm{~h}$ in the presence of DMEM, $\mathrm{H}-16$ supplemented with $2.5 \mu \mathrm{g} / \mathrm{ml}$ Fungizone, $50 \mu \mathrm{g} / \mathrm{ml}$ gentamycin, and with either $10 \%$ plasma or serum. After $8 \mathrm{~h}$, the media were removed and the cultures washed once with DMEM, H-16. DMEM, H-16 supplemented with $2.5 \mu \mathrm{g} / \mathrm{ml}$ Fungizone and $50 \mu \mathrm{g} / \mathrm{ml}$ gentamycin, and containing different concentrations of serum or plasma (from 0.25 to $10 \%$ ), was then added to the dishes. FGF ( $100 \mathrm{ng} / \mathrm{ml})$ was added every other day to some of the dishes. After $6 \mathrm{~d}$ the cultures were trypsinized and counted. Cultures maintained on plastic and exposed to plasma ( $\square$, P plasma) or to plasma and FGF ( $\square$, $P+F$ plasma); cultures maintained on plastic and exposed to serum $(\Delta, P$ serum $)$ or to serum and FGF $(\Delta, P+F$ serum); cultures maintained on an ECM and exposed to plasma $(\boldsymbol{Q}, \mathrm{EM}$ plasma) or to serum (O, EM serum).

main collagen components of basement membrane in vivo, can only be extracted from tissue after proteolysis. This could result in structural alterations and prevent their proper polymerization in vitro.

In contrast to most cell types, corneal endothelial cells maintained in tissue culture retain their ability to synthesize and secrete an ECM found underneath but not on top of the cells. This ECM, whose appearance has been shown to correlate with the acquisition by cultured corneal endothelial cells of their normal "in vivo" morphology, cell surface polarity, and function (9), could substitute for the ECM produced by other

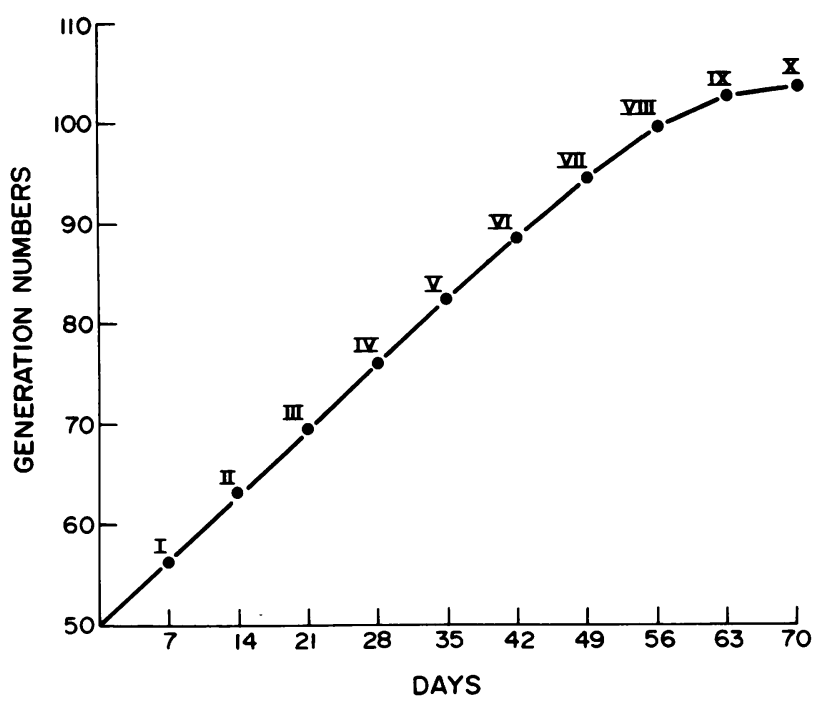

FIGURE 9 Effect of the ECM on the culture lifetime of bovine vascular endothelial cells. Bovine vascular endothelial cells previously maintained on plastic tissue culture dishes and grown in the presence of FGF ( $100 \mathrm{ng} / \mathrm{ml}$ added every other day) $(10,17)$ for 50 generations were maintained and passaged weekly on dishes coated with an ECM as described in Methods. FGF was no longer added to the cultures. The number of generations was determined from the initial cell density $8 \mathrm{~h}$ after seeding and the number of cells harvested at each transfer. Each point represents a single transfer. The average growth rate is given by the slope. Roman numbers indicate the passage number.

cell types. The ability of corneal endothelial cells in tissue culture to produce such extensive extracellular material could help us to understand its role in controlling the mitogenic response of other cell types when maintained on it and exposed to growth factors that are usually tested on cells maintained on plastics.

When the proliferation of bovine vascular endothelial cells plated at low density on plastic dishes vs. dishes coated with an ECM is compared, it is observed that, although cells maintained on plastic and exposed to serum proliferated slowly, thereby requiring FGF in order to become confluent, when maintained on an ECM they proliferated quite actively and no longer required FGF in order to become confluent. Therefore, one can conclude that the close contact of the cells with the ECM must make bovine vascular endothelial cells responsive to factors present in serum, and that adherence to plastic prevents such a response. That this is a likely explanation can be inferred from the observation that bovine vascular endothelial cells maintained on an ECM had a faster growth rate when maintained in high than in low serum or plasma concentrations, thereby exhibiting a dependence on serum as well as plasma in order to proliferate. Furthermore, when bovine vascular endothelial cells are maintained at low cell density on an ECM, not only do they lose 
their dependence on FGF but they will proliferate as well in response to plasma as to serum. Therefore, one can conclude that the simple change of substrate from plastic to ECM will restore the sensitivity of these cells to physiological agents present in plasma. The present results also show conclusively that cells cloned and grown in the presence of FGF do not, as suggested by Schwartz et al. (50), represent a subpopulation of endothelial cells selected for their special response to FGF because, when grown on a natural substrate such as an ECM, they no longer require FGF in order to proliferate and will respond to plasma, which is the fluid to which they are exposed in vivo. Further proof that cells cloned and continuously passaged in the presence of FGF are not selected for their sensitivity to FGF can also be derived from the observation that cultures that have been propagated on plastic in the presence of FGF for 50 generations can then be repeatedly passaged on an ECM in the absence of FGF and will still grow vigorously. Experiments are in progress to determine how long cells can be maintained on an ECM while still proliferating actively. It is particularly important to determine whether the addition of FGF to such cultures before or during their eventual senescence can restore an active state of proliferation and delay their terminal differentiation.

Although FGF is clearly mitogenic for a number of mesoderm-derived cells (51), its action on some of the cell types could be indirect. It could either replace the cellular requirement for a substrate such as the ECM and thereby make the cells fully responsive to growth factors present in serum and plasma even when the cells are maintained on plastic, or, alternatively, it could control the synthesis and secretion of the ECM produced by the cells. Such control could in turn make the cells sensitive to factors present in serum or plasma. That the latter alternative could occur is supported by earlier observations, which demonstrate that FGF, in the case of vascular endothelial cells, can control the production by the cells of extracellular and cell-surface components such as fibronectin and various types of collagent $(24,52)$ that could exert a permissive effect on cell proliferation.

Evidence that FGF can also directly affect cell proliferation is provided by human umbilical endothelial cells. Although a greatly increased growth rate is observed when that cell type is maintained on ECM, the cultures do not reach confluence unless FGF is added to the medium.

Our repeated observation $(8-10,17,24,52)$ that FGF is a potent mitogen for low density vascular endothelial cell cultures stands in constrast to communications by others who have reported that FGF does not affect the proliferation of either bovine $(50,53)$ or human vascular endothelial cells (54) maintained on plastic (52-54). Although Schwartz et al. (50) claim to have tested FGF with bovine vascular endothelial cells under our conditions, this was clearly not the case. Neither the cell density (200 cells $\left./ \mathrm{mm}^{2}\right)$ at which cultures were started nor the medium (Waymouth) or serum (fetal calf serum) were as described by us $(8-10$, 17). Under our conditions, the initial cell density at which cultures are started is 20 -fold lower $\left(10\right.$ cells $\left./ \mathrm{m}^{2}\right)$, whereas the medium is DMEM, $\mathrm{H}-16$ and the serum is calf serum. It is well known that the cell density at which cultures are started subsequently affects their rates of proliferation. This mostly reflects the ability of cells to rapidly condition their medium at high, but not at low, cell density. The high cell density used by Schwartz et al. (50), which is one fourth to one fifth that of confluent cultures, although it leaves little room for cells to divide, nevertheless gives them the opportunity to condition their medium rapidly $(24,52)$, thereby greatly decreasing the effect of any growth-promoting agents. If such experiments had been repeated under proper conditions (media and sera) and at very low cell density, conditions under which cells can undergo multiple replicative cycles before becoming confluent, it is likely that their outcomes would have been different. It is also common knowledge that both medium and serum to which cells are exposed can greatly affect their response to growth factors. We have previously reported that fetal calf serum, in contrast to calf serum, does not support the mitogenic effect of FGF on vascular endothelial cells (8). Likewise, we have also observed that Waymouth medium does not support the growth of vascular endothelial cells when seeded at low density (55). In fact, similar results were also reported by Schwartz (23), who first observed that when vascular endothelial cells are maintained in Waymouth medium, they can only be passaged at a low split ratio of 1 to 2 or 1 to 4 . Although in their early passage the cultures had an average doubling time of $4 \mathrm{~d}$, as passage number increased, the average doubling time of the cultures increased to 7-8 d (23). The inability of the cultures to be passaged at a reasonably low cell density, as well as their extremely long doubling time, could directly reflect the inadequacy of the medium to which they were exposed.

In a recent communication (54), Maciag et al. described the identification of a new growth factor, endothelial cell growth factor, which they isolated from bovine brain tissue. They also reported, in contrast to our previous findings $(10,17)$, that neither brain nor pituitary FGF stimulated the proliferation of human umbilical endothelial cells grown on plastic dishes. Although they stated that their purification scheme is similar to the one we described (11), it in fact differs from our own at a single but quite critical point. Although we showed that brain and pituitary tissue must be extracted at $\mathrm{pH} 4.5$ in the presence of $0.15 \mathrm{M}$ $\left(\mathrm{NH}_{4}\right)_{2} \mathrm{SO}_{4}$ to extract FGF $(11,55)$, Maciag et al. have 
been extracting the tissues in unbuffered saline, i.e., without $\mathrm{pH}$ control and with a $\mathrm{pH}(6.5-7.0)$ near neutrality. In 1975, we reported the characterization from brain and pituitary tissue of a factor we named by its activity on the first cell type upon which it was tested, viz., myoblast growth factor (56). This factor is, in all likelihood, the same as endothelial cell growth factor because it is preferentially, if not exclusively, extracted at basic (8.5) as well as neutral (7.0) $\mathrm{pH}$, but not at acidic $\mathrm{pH}$ (54). In contrast, we have shown that FGF can only be extracted at an acidic $\mathrm{pH}$ of 4.5 ; extraction at neutral or basic $\mathrm{pH}$ results in the solubilization of little or no FGF activity, whereas extraction at $\mathrm{pH}<4.0$ inactivate FGF $(11,55,56)$. This change in extraction procedure (i.e., extraction at neutral $\mathrm{pH}$, which results in failure to extract $\mathrm{FGF}$ ) probably explains Maciag et al. findings that their preparations of brain or pituitary FGF do not stimulate proliferation of vascular endothelial cells.

The demonstration that the substrate upon which vascular endothelial cells rests can greatly affect their survival, proliferative rate, and lifetime in culture could lead to the establishment in culture of vascular endothelial territories that do not adapt readily to in vitro conditions when cells are maintained on plastic. It could also make the study of various metabolic functions of the endothelium in vitro more feasible, because maintaining cells on an ECM is a closer approximation to the in vivo situation than maintaining them on plastic. Finally, cell migration has been shown to be strongly affected by the substrate upon which cells rest $(18,40)$. This activity represents an important part both in vivo and in vitro of the regeneration process of the endothelium after trauma. It has been shown by others (50) that there are substantial differences between the regeneration of the endothelium in vivo and in vitro when cells are maintained on plastic. Whether such differences would be observed if cells were maintained on an ECM rather than on plastic, remains a question.

\section{ACKNOWLEDGMENTS}

We wish to thank Mr. Harvey Scodel for his invaluable assistance in the preparation of this manuscript.

This work was supported by grant HL 20197 from the National Institutes of Health.

\section{REFERENCES}

1. Gospodarowicz, D., G. Greenburg, and C. R. Birdwell. 1978. Cellular shape is determined by the extracellular matrix and is correlated with the control of cell growth. Cancer Res. 38: 4155-4171.

2. Gospodarowicz, D., G. Greenburg, I. Vlodavsky, J. Alvarado, and L. K. Johnson. 1979. Identification and localization of fibronectin in cultured corneal endothelial cells. Exp. Eye Res. 29: 485-509.

3. Gospodarowicz, D., I. Vlodavsky, G. Greenburg, J. Alvarado, L. K. Johnson, and J. Moran. 1979. Studies on atherogenesis and corneal transplantation using cultured vascular and corneal endothelia. Recent. Prog. Horm. Res. 35: 315-377.

4. Grobstein, C. 1967. Mechanisms of organogenetic tissue interaction. Natl. Cancer Inst. Monogr. 26: 279-299.

5. Grobstein, C. 1975. Developmental role of intracellular matrix: retrospective and prospective. In Extracellular Matrix Influences on Gene Expression. H. C. Slavkin and R. C. Greulich, editors. Academic Press, Inc., New York. 9-16, 809-814.

6. Slavkin, H. C., G. N. Trump, A. Brownell, and N. Sorgente. 1977. Epithelial-mesenchymal interactions: mesenchymal specificity. Soc. Gen. Physiol. Ser. 32: 23-46.

7. Gospodarowicz, D., D. Delgado, and I. Vlodavsky. 1980. Control of cell proliferation in vitro by the extracellular matrix. Proc. Natl. Acad. Sci. U. S. A. In press.

8. Gospodarowicz, D., J. Moran, D. Braun, and C. R. Birdwell. 1976. Clonal growth of bovine endothelial cells in tissue culture: fibroblast growth factor as a survival agent. Proc. Natl. Acad. Sci. U. S. A. 73: 4120-4124.

9. Gospodarowicz, D., J. Moran, and D. Braun. 1977. Control of proliferation of bovine vascular endothelial cells. J. Cell. Physiol. 91: 377-385.

10. Gospodarowicz, D., G. Greenburg, H. Bialecki, and B. Zetter. 1978. The role of fibroblast and epidermal growth factor in the proliferative response of mammalian cells. In Vitro (Rockville). 14: 85-118.

11. Gospodarowicz, D., H. Bialecki, and G. Greenburg. 1978. Purification of the fibroblast growth factor activity from bovine brain. J. Biol. Chem. 253: 3736-3744.

12. Ross, R., J. Glomset, B. Kariya, and L. Harker. 1974. A platelet-dependent serum factor that stimulates the proliferation of arterial smooth muscle cells in vitro. Proc. Natl. Acad. Sci. U. S. A. 71: 1207-1210.

13. Ross, R., C. Nist, B. Kariya, M. J. Rivest, E. Raines, and J. Callis. 1978. Physiological quiescence in plasma-derived serum: influence of platelet-derived growth factor on cell growth in culture. J. Cell. Physiol. 97: 497-508.

14. Gospodarowicz, D., A. L. Mescher, and C. R. Birdwell. 1977. Stimulation of cornea endothelial cell proliferation in vitro by fibroblast and epidermal growth factors. Exp. Eye Res. 25: 75-87.

15. Gospodarowicz, D., and G. Greenburg. 1978. The coating of bovine and rabbit corneas denuded of their endothelium with bovine corneal endothelial cells. Exp. Eye Res. 28: 249-265.

16. Jaffe, E. A., R. L. Nachman, C. G. Becker, and R. Minick. 1973. Culture of human endothelial cells derived from umbilical veins: identification by morphological and immunological criteria. J. Clin. Invest. 52: 2257-2276.

17. Gospodarowicz, D., K. S. Brown, C. R. Birdwell, and B. R. Zetter. 1978. The control of proliferation of vascular endothelial cells of human origin. I. Characterization of the response to human umbilical endothelial cells to the fibroblast growth factor, epidermal growth factor, and thrombin. J. Cell Biol. 77: 774-789.

18. Vlodavsky, I., G. M. Lui, and D. Gospodarowicz. 1980. Morphological appearance, growth behavior, and migratory activity of human tumor cells maintained on extracellular matrix versus plastic. Cell. 19: 607-617.

19. Liu, S-C., and M. Karaseck. 1978. Isolation and growth of adult human epidermal keratinocytes in cell culture. J. Invest. Dermatol. 71: 157-165.

20. Murray, J. C., G. Stingl, H. K. Kleinman, G. R. Martin, and S. I. Katz. 1979. Epidermal cells adhere preferentially to type IV (basement membrane) collagen. J. Cell Biol. 80: $197-202$.

21. Orly, J., and G. Sato. 1979. Fibronectin mediates cyto- 
kinesis and growth of rat follicular cells in serum-free medium. Cell. 17: 295-305.

22. Gospodarowicz, D., and C. R. Ill. 1980. Plasma versus serum. Is there a difference in their ability to promote cell growth? Proc. Natl. Acad. Sci. U. S. A. In press.

23. Schwartz, S. M. 1978. Selection and characterization of bovine aortic endothelial cells. In Vitro (Rockville). 14: 966-980.

24. Vlodavsky, I., L. K. Johnson, G. Greenburg, and D. Gospodarowicz. 1979. Vascular endothelial cells maintained in the absence of fibroblast growth factor undergo structural and functional alterations that are incompatible with their in vivo differentiated properties. J. Cell Biol. 83: $468-483$.

25. Gimbrone, M. A., Jr. 1976. Culture of vascular endothelium. Prog. Hemostasis Thromb. 3: 1-28.

26. Macarak, E. J., E. Kirby, T. Kork, and N. A. Kefalides. 1978. Synthesis of cold insoluble globulin by cultured calf endothelial cells. Proc. Natl. Acad. Sci. U. S. A. 75: 2621-2625.

27. Weksler, B. B., A. J. Marcus, and E. A. Jaffe. 1977. Synthesis of prostacyclins by cultured human and bovine endothelial cells. Proc. Natl. Acad. Sci. U. S. A. 74: 39223926.

28. Booyse, F. M., B. J. Sedlak, and M. E. Rafelson, Jr. 1975. Culture of arterial endothelial cells: characterization and growth of bovine aortic cells. Thromb. Diath. Haemorrh. 34: 825-839.

29. Miller, E. J. 1977. The collagen of the extracellular matrix. In Cell and Tissue Interactions. J. W. Lash and M. M. Burger, editors. Society of General Physiologists Series. Raven Press, New York. 32: 71-86.

30. Muir, H. 1977. Structure and function of proteoglycans of cartilage on a cell matrix interaction. Soc. Gen. Physiol. Ser. 32: 32-42.

31. Stenman, S., and A. Vaheri. 1978. Distribution of a major connective tissue protein, fibronectin, in normal human tissues. J. Exp. Med. 147: 1054-1063.

32. Dodson, J. S. 1963. On the nature of tissue interactions in embryonic skin. Exp. Cell Res. 31: 233-235.

33. Wessels, N. K. 1964. Substrate and nutrient effect upon epidermal basal cell orientation and proliferation. Proc. Natl. Acad. Sci. U. S. A. 52: 252-259.

34. Cohen, S. 1972. The stimulation of epidermal cell proliferation by a specific protein (EGF). Dev. Biol. 12: 394-407.

35. Grobstein, C. 1975. Developmental role of intercellular matrix: retrospective and prospective. In Extracellular Matrix Influences on Gene Expression. H. C. Slavkin and R. C. Greulich, editors. Academic Press, Inc., New York. 9-16, 809-814.

36. Bernfield, M. R. 1978. Embryonic induction and tissue interaction during morphogenesis. Excerpta Med. Int. Congr. Ser. 432: 111-125.

37. Ehrmann, R. L., and G. O. Gey. 1956. The growth of cells on a transparent gel of reconstituted rat tail collagen. $J$. Natl. Cancer Inst. 16(2): 1375-1402.

38. Schar, S. L., and J. Court. 1979. Different mechanisms in the attachment of cells to native and denaturated collagen. J. Cell Sci. 38: 267-281.

39. Sicha, M. S., L. A. Liotta, S. Garbioa, and W. R. Kidwell. 1979. Basement membrane collagen requirements for attachment and growth of mammary epithelium. Exp. Cell Res. 124: 181-196.

40. Fisher, M., and M. Solursh. 1979. The influence of the substratum on mesenchyme spreading in vitro. Exp. Cell Res. 123: 1-14.
41. Gey, G. O., M. Svotelis, M. Foard, and F. B. Band. 1974 Long-term growth of chicken fibroblasts on a collagen substrate. Exp. Cell Res. 84: 63-71.

42. Liotta, L. A., D. Vembu, H. K. Kleinman, G. R. Martin and C. Boone. 1978. Collagen required for proliferation of cultured connective tissue cells but not their transformed counterparts. Nature (Lond.). 272: 622-624.

43. Yang, J., J. Richards, P. Bowman, R. Guzman, J. Ehami, K. McCormick, S. Hamamoto, D. Pitelka, and S. Nandi. 1979. Sustained growth and three-dimensional organization of primary mammary tumor epithelial cells embedded in collagen gels. Proc. Natl. Acad. Sci. U. S. A. 76: 34013405.

44. Konigsberg, I. R., and S. D. Hauschka. 1965. Cell and tissue interactions in the reproduction of cell type. In Reproduction: Molecular, Subcellular and Cellular. M. Locke, editor. Academic Press, Inc., New York. 243-290.

45. Kosher, R. A., and R. L. Church. 1975. Stimulation of in vitro somite chondrogenesis by procollagen and collagen. Nature (Lond.). 258: 327-330.

46. Lash, J. W., E. Belsky, and N. S. Vasan. 1977. Stimulation of chondrogenic differentiation with extracellular matrix components: an analysis using scanning electron microscopy. In Cell Interactions in Differentiation. M. KarkininJaaskelainen, L. Saxen, and L. Weiss, editors. Academic Press, Inc., New York. 263-272.

47. Meier, S., and E. D. Hay. 1975. Stimulation of corneal differentiation by interaction between cell surface and extracellular matrix. J. Cell Biol. 66: 275-291.

48. Yamada, K. J., S. S. Yamada, and I. Pastan. 1976. Cell surface protein partially restores morphology, adhesiveness and contact inhibition of movement to transformed fibroblasts. Proc. Natl. Acad. Sci. U. S. A. 73: 12171221.

49. Ali, I. U., V. Mautner, R. Lanza, and R. O. Hynes. 1977. Restoration of normal morphology: adhesion and cytoskeleton in transformed cells by addition of a transformation-sensitive surface protein. Cell. 11: 115-126.

50. Schwartz, S. M., S. C. Ill, and P. Bowman. 1979. Growth control in aortic endothelium at wound edges. Cold Spring Harbor Conf. Cell Proliferation. 6: 593-610.

51. Gospodarowicz, D., A. L. Mescher, and C. R. Birdwell. 1978. The control of cellular proliferation by the fibroblast and epidermal growth factors. Natl. Cancer Inst. Monog. 48: 109-130.

52. Greenburg, G., I. Vlodavsky, and D. Gospodarowicz. 1980. Medium from endothelial cell cultures can restore the normal phenotypic expression of vascular endothelium maintained in vitro in the absence of fibroblast growth factor. J. Cell Physiol. In press.

53. Striker, G. E., J. M. Harlan, and S. M. Schwartz. 1980. In Cultured Human Tissues and Cells in Biomedical Research. Academic Press, Inc., New York. In press.

54. Maciag, T., J. Cerundolo, S. Isley, P. R. Kelley, and R. Forand. 1979. An endothelial cell growth factor from bovine hypothalamus: identification and partial characterization. Proc. Natl. Acad. Sci. U. S. A. 76: 5674-5678.

55. Gospodarowicz, D. 1979. Fibroblast and epidermal growth factors: their uses in vivo and in vitro in studies on cell functions and cell transplantation. Mol. Cell. Biochem. 25: 88-95.

56. Gospodarowicz, D., J. Weseman, and J. Moran. 1975. Presence in brain of a mitogenic agent promoting proliferation of myoblasts in low density culture. Nature (Lond.). 256: 216-219. 